\title{
Mann-Kendall, and Sen's Slope Estimators for Precipitation Trend Analysis in North-Eastern States of India
}

\author{
Neel Kamal \\ Research Scholar, \\ Faculty of Computing and Information Technology \\ Himalayan University \\ Arunachal Pradesh
}

\author{
Sanjay Pachauri, PhD \\ Head of Department, CSE/IT, \\ IIMT College of Engineering, \\ Greater Noida, U.P.
}

\begin{abstract}
The cause of climate change detection is very tedious and complex phenomenon. For the purpose, the behaviour identification of climatic variable using long term historical database is very important. In present study, highlights the climatic variability has been identified using the nonparametric Mann-Kendall, and Sen's slope estimators over north-eastern region of India. In this study long term precipitation data has been considered during 1901-2015. The non-parametric tests have been tested at the $5 \%$ level of significance. The non-parametric tests were applied at eight north-eastern states i.e., Arunachal Pradesh, Assam, Manipur, Meghalaya, Mizoram, Nagaland, Tripura and West-Bengal of India. This type of study is very necessary for long-term agricultural and water resources planning of the states.
\end{abstract}

\section{Keywords}

Mann-Kendall test, Sen's slope estimators, North-Eastern states, Climate Change

\section{INTRODUCTION}

For a developing country like India, which has agriculture based economy, the uncertainty and non-uniformity associated with rainfall characteristics could result in severe reduction in agricultural production and could adversely affect the water resources planning and management to meet demands for various purposes such as irrigation, domestic and hydropower. Among various hydro-climatic variables (rainfall, evapotranspiration, temperature, humidity), rainfall is the most important and most studied variable because of its significance for sustainable water, agriculture and ecological management (Chowdhury et al., 2014). The changing rainfall patterns and its impact on water resources is an important climatic problem facing society today. Associated with global warming, there are strong indications that rainfall changes are already taking place on both the global (Bradley et al., 1987) and regional scales (Maheras, 1988). Future climate changes may involve modifications in climatic variability as well as changes in averages (Rind et al., 1989).

Several researchers have investigated rainfall characteristics, variability and trends and have identified mechanisms for these changes, e.g., in United States (Alexander et al., 2006); Spain (De Luis et al., 2000); Australia (Hasan and Dunn, 2011), Upper Blue Nile river basin (Tabari et al., 2015); Malaysia (Loo et al., 2015); India (Lacombe and McCartney, 2014); and around the world (Rauch and DeToffol, 2006) and could be taken as the noteworthy works. Spatial and temporal trends in extreme precipitation intensity were also observed in Japan (Fujibe et al. 2005), India (Kumar et al., 2010), China
(Wang and Zhou, 2005), and South Africa (Sen Roy and Rouault, 2013).

In Indian context, the studies done by Khan et al., (2000); Shrestha et al., (2000); Mirza, (2002); Goswami et al., (2006); Dash et al., (2007) found that, in general, the frequency of more intense rainfall events in many parts of Asia has increased, while the number of rainy days and total annual amount of precipitation has decreased. Goswami et al. (2006) used daily rainfall data to show the significant rising trends in the frequency and magnitude of extreme rain events, and a significant decreasing trend in the frequency of moderate events over central India during the monsoon seasons from 1951 to 2000. Mirza et al. (1998) carried out trend and persistence analysis for the Ganges, Brahmaputra and Meghna river basins. They showed that precipitation in the Ganges basin is, by and large, stable. Furthermore, one of three subdivisions of the Brahmaputra basin shows a decreasing trend, while another shows an increasing trend. Singh et al. (2008) studied the changes in rainfall in nine river basins of northwest and central India and found an increasing trend in annual rainfall in the range of $2-19 \%$ of the mean per 100 years. Sinha Ray \& De (2003) concluded that all-India rainfall and surface pressure shows no significant trend, except for some periodic behaviour. According to Sinha Ray \& Srivastava (1999), the frequency of heavy rainfall events during the southwest monsoon has shown an increasing trend over certain parts of the country, whereas a decreasing trend has been observed during winter, pre-monsoon and postmonsoon seasons.

\section{STUDY AREA}

In the present study, North-East region of India is considered as a study area. In this region various states are considered i.e., Arunachal Pradesh, Assam, Manipur, Meghalaya, Mizoram, Nagaland, Tripura and West-Bengal. The Location details and area description are shown in Table 1 as follows:

Table 1: Location details and area description of NorthEastern states

\begin{tabular}{|c|c|c|c|}
\hline $\begin{array}{c}\text { S. } \\
\text { No. }\end{array}$ & $\begin{array}{c}\text { North- } \\
\text { Eastern } \\
\text { States }\end{array}$ & $\begin{array}{c}\text { Location } \\
\text { Details }\end{array}$ & Area $\mathbf{( k m}^{2}$ ) \\
\hline 1 & $\begin{array}{c}\text { Arunachal } \\
\text { Pradesh, }\end{array}$ & $\begin{array}{c}28.2180^{\circ} \mathrm{N}, \\
94.7278^{\circ} \mathrm{E}\end{array}$ & 83,743 \\
\hline 2 & Assam & $\begin{array}{c}26.2006^{\circ} \mathrm{N}, \\
92.9376^{\circ} \mathrm{E}\end{array}$ & 78,438 \\
\hline 3 & Manipur & $24.6637^{\circ} \mathrm{N}$, & 22,327 \\
\hline
\end{tabular}




\begin{tabular}{|c|c|c|c|}
\hline & & $93.9063^{\circ} \mathrm{E}$ & \\
\hline 4 & Meghalaya & $\begin{array}{l}25.4670^{\circ} \mathrm{N}, \\
91.3662^{\circ} \mathrm{E}\end{array}$ & 22,720 \\
\hline 5 & Mizoram & $\begin{array}{l}23.1645^{\circ} \mathrm{N}, \\
92.9376^{\circ} \mathrm{E}\end{array}$ & 21,081 \\
\hline 6 & Nagaland & $\begin{array}{l}26.1584^{\circ} \mathrm{N}, \\
94.5624^{\circ} \mathrm{E}\end{array}$ & 16,579 \\
\hline 7 & Tripura & $\begin{array}{l}23.9408^{\circ} \mathrm{N}, \\
91.9882^{\circ} \mathrm{E}\end{array}$ & 10,492 \\
\hline 8 & $\begin{array}{c}\text { West- } \\
\text { Bengal }\end{array}$ & $\begin{array}{c}22.9868^{\circ} \mathrm{N}, \\
87.8550^{\circ} \mathrm{E}\end{array}$ & 88,752 \\
\hline
\end{tabular}

S Arunachal Pradesh, Assam, Manipur, Meghalaya, Mizoram, Nagaland, Tripura and West-Bengal states are lies in NorthEastern part of India. As concern with climatic description of India, the highest average annual rainfall received about $11,873 \mathrm{~mm}$ in Mawsynram, Meghalaya which is also located in North-Eastern part of India. The monsoon season starts from June and end up to September in this region. The location map of study area is shown in Figure 1.

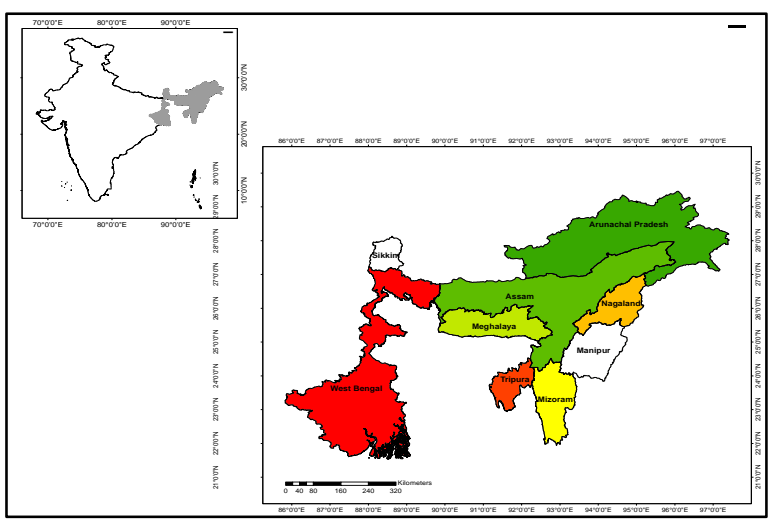

Figure1. Location map of study area

\section{METHODOLOGY}

\subsection{Data Requirement and Availability}

Present study requires long term (1901-2015) daily precipitation data, for the purpose fine India Meteorological Department (IMD) gridded $(0.25 \mathrm{deg} \times 0.25 \mathrm{deg})$ data to be utilized. The gridded data base to be converted in to area weighted average rainfall for each state. Further data mining techniques has been utilized for further process viz. monthly and seasonal conversion. The entire data sets have been converted in to annual and seasonal time series. GIS administrative boundary of the entire districts shape files are downloaded from DIVA-GIS web-site.

\subsection{Trend Analysis}

To investigate the spatial and temporal changes in rainfall for different seasons, a year has been divided into four seasons: winter (December-February), pre-monsoon (March-May), monsoon (June-September), and post-monsoon (OctoberNovember). For the trend analysis, monthly rainfall series were used to form seasonal and annual series. Generally, rainfall data used in the studies of rainfall trends should only be affected by weather and climate conditions; however, other factors like location of the station, station environment, observing practices and instruments may also influence the homogeneity of rainfall time series (Chen et al., 2015).
Further, as discussed above, the long term rainfall series may also have serial auto-correlations and therefore, before conducting further investigations, the rainfall series is tested for homogeneity using standard normal homogeneity test (SNHT) test and TFPW approach is used to make the series free from auto-correlations.

Long term trend analysis has been performed for each districts on the basis of monthly, seasonal and annual basis. SNHT has been for checking the homogeneity of long term data series at 5\% significance level (Alexandersson 1986; Alexandersson; Moberg 1997). The critical values of SHNT statics T0 for various sample sizes (10 to 250$)$ were originally developed from using relatively short Monte Carlo simulations with different critical percentage (Khaliqa and Ouardab, 2007). The series is homogeneous if the critical value of the SHNT statics T0 for 115 sample size at $95 \%$ critical level is less than 11.32 .

In present study, long term rainfall trend analysis has been carried out using the Mann Kendall (MK) Test. However, MK test is most appropriate test for identification of monotonic trend in persistent data and is considered as better than other parametric tests (Mann, 1945). The MK test is one of the most commonly used non-parametric method, most of the literature significantly contains this approach for trend analysis (Buffoni et al. 1999; Déry; Wood 2005; Kumar; Jain 20210; Mondal et al. 2012a; Xu et al. 2003; Zhang et al. 2008). Magnitude of trend has been quantified by Theil-Sen's estimator (Duhan; Pandey 2013; Jhajharia et al. 2012) and positive and negative values of magnitude showed increasing and decreasing trend respectively. Results of trend has been shown in terms of positive significant, negative significant, positive nonsignificant and negative non-significant level of rainfall at 5\% level of significance (Mondal et al. 2012b).

\section{RESULTS AND DISCUSSIONS 4.1 Extraction of IMD daily fine resolution data (1901-2015) and processing}

Extraction of IMD fine resolution data has been procured from Indian Meteorological Department, Pune. The daily gridded data are available in .txt format. The data has been extracted by using the MATLAB programming. In this study there are nine states are considered for detection of climatic variability using data mining technique. Initially daily rainfall data has been extracted for each of the fine resolution grids ( 0.25 deg. x 0.25 deg.). The total 98 grids lie over the entire nine states. Further, weighted average rainfall has been estimated by using the Thiessen polygon interpolation technique. The IMD grids arrangements over nine states are shown in Figure 2 below:

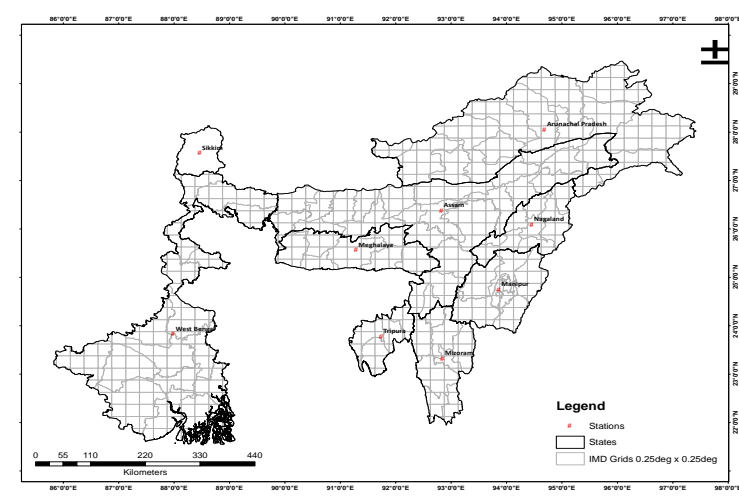

Figure 2: Location of stations and IMD fine resolution grid arrangements over NE state boundary 


\subsection{Preparation of GIS layers for study area}

The GIS layers as well as maps have been prepared using the ArcMap 10.4. The administrative boundary of the state is downloaded from the DIVA-GIS site. The fine resolution grids are prepared using the add XY command in ArcMap 10.4. Stations are located in the centroid of the states using feature to point command in ArcMap 10.4. Further, applied the Thiessen Polygon commands over imported points, the grids are automatic generated shown in Figure 2.

\subsection{Calculation of area weighted average rainfall and its statistics for each state}

4.3.1 Preliminary data analysis

The weighted average of rainfall also calculated using the ArcMap 10.4. Initially, the two layers have been prepared state boundary and Thiessen grids. Further, intersect command has been used to super-impose the both layers and calculated the intersected area of each grids over the state Thereafter, weighted average rainfall has been calculated for each of the state. General statistics of annual rainfall time series during 1901-2015 over North-East states shown in Table 2.

Table 2: General statistics of annual rainfall time series during 1901-2015 over North-East states

\begin{tabular}{cccccc}
\hline States & Observations & Minimum & Maximum & Mean & Std. deviation \\
\hline Arunachal Pradesh & 115 & 1227.1 & 4426.3 & 2634.6 & 622.2 \\
Assam & 115 & 1474.6 & 2744.3 & 2218.6 & 234.6 \\
Manipur & 115 & 857.3 & 2248.1 & 1515.6 & 246.5 \\
Meghalaya & 115 & 1300.3 & 6345.0 & 2781.5 & 821.2 \\
Mizoram & 115 & 1071.1 & 3089.7 & 1881.9 & 369.8 \\
Nagaland & 115 & 1162.4 & 2453.0 & 1929.5 & 270.1 \\
Sikkim & 115 & 1640.6 & 3814.0 & 2765.1 & 386.4 \\
Tripura & 115 & 1294.2 & 3508.2 & 2331.2 & 377.3 \\
West Bengal & 115 & 1348.3 & 2240.0 & 1775.0 & 193.5 \\
\hline
\end{tabular}

General statistical parameters (Minimum, maximum, mean and standard deviation) of annual rainfall time series are calculated for each states of North-Eastern India. Annual rainfall varies between $857.3 \mathrm{~mm}$ (Manipur) to $6345 \mathrm{~mm}$ (Meghalaya) over the entire states. Weighted annual average rainfall of the entire state is calculated as $2203.67 \mathrm{~mm}$. From the analysis, it has been observed that the standard deviation varies between $193.5 \mathrm{~mm}$ (West-Bengal) to $821.2 \mathrm{~mm}$ (Meghalaya) shown in Table 2. It can be concluded from the analysis that the zone of usually heavy rainfall shows complex variability and zone of low rainfall indicates less variability.

\subsubsection{Conversion of data sets in to annual and seasonal time series using data mining technique}

In this study, the entire daily gridded rainfall time series have been converted into monthly time series during 1901-2015. Before, applying the non-parametric trend analysis the monthly rainfall has been converted into annual and seasonal time series. The seasons are defined as per IMD i.e., premonsoon (March-May), monsoon (June-September), postmonsoon (October-December) and winter (January-February). The entire analysis has been done on the basis of monthly, annual and seasonal basis. Weighted average time series has been prepared using the GIS analysis.

\subsection{Rainfall trend analysis during 1901- 2015}

\subsubsection{Results of Mann-Kendall (MK) Test}

In this time series, MK test is analyzed on monthly, annual and seasonal basis. In monthly time step, the total values are $9 \times 12=108$, out of them most of the values (63 values) are showing negative trends and remaining (45 values) are positive. In annual time series, out of nine states five states showing negative trends and remaining are positive. However, out of nine states two states (Meghalaya and Mizoram) are showing significant positive and two states (Nagaland and Assam) showing significant negative trends at 5\% significant level. Most of the significant trends have been shown in monsoon season. In monsoon season, two states (Meghalaya and Mizoram) showing significant positive and four states (Arunachal Pradesh, Assam, Nagaland and Sikkim) showing significant negative trends. In pre-monsoon season five states showing positive trend and four are negative. Whereas, one state (Nagaland) showing negative significant trend and two states (Meghalaya and Sikkim) showing positive significant trends. In post monsoon season, out of nine states five states are showing negative trends. However, two states (Meghalaya and Mizoram) are showing significant positive and one state (Nagaland) is showing significant negative trend. In winter season, most of the states are showing negative trend except two states (Arunachal Pradesh and Sikkim). Whereas, Assam and Nagaland are shows significant negative trends and Sikkim is showing significant positive trend. In totality, the states are falls under negative trends during 1901-2015.

\subsubsection{Estimated magnitude of rainfall using} Sen's slope estimator

Magnitude of monthly, annual and seasonal rainfall data is estimated by Sen's slope estimator and it has been represented in to box plots shown in Figure 3(a) and Figure 3(b). Figure 3(a) shows the box plots of different slope (in $\mathrm{mm} /$ day) values of different states at monthly time steps. Whereas the Figure 3 (b) shows the box plots of different slope (in $\mathrm{mm} /$ day) values of different states at annual and seasonal time steps. In monthly time steps, the lowest value (Sikkim)for the slope of rainfall $(-1.805 \mathrm{~mm} / \mathrm{year})$ trend line wasfound in August 
month during 1901-2015, and thehighest value (Meghalaya) for the slope of rainfall $(2.408 \mathrm{~mm} /$ year $)$ trend line was found in July month during 1901-2015 shown in Figure 3(a). In annual and seasonal time steps, the lowest value (Sikkim)for the slope of rainfall $(-4.764 \mathrm{~mm} /$ year) trend line was found in the monsoon season during 1901-2015, and the highest value

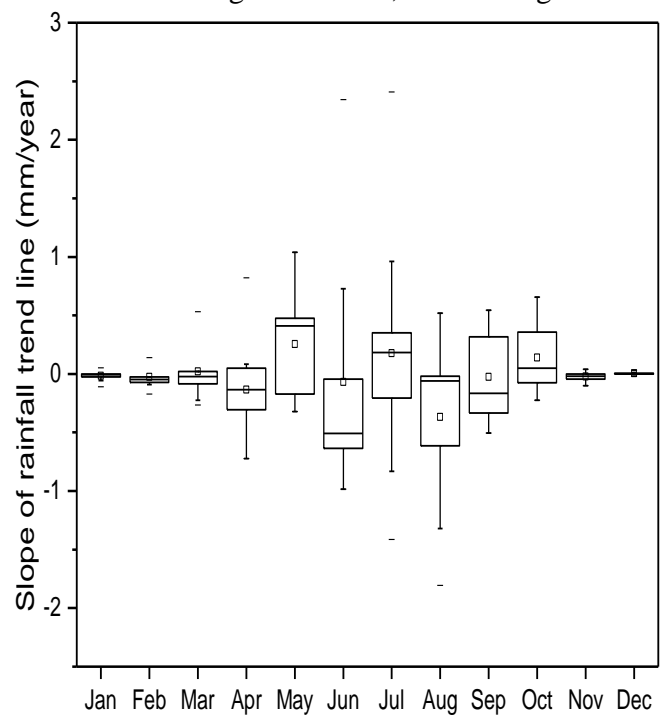

Figure 3(a): Box plot of the Theil-Sen's slopes in monthly time step
(Meghalaya) for the slope of rainfall $(9.241 \mathrm{~mm} /$ year)trend line was found in the annual time scale during 1901-2015 shown in Figure 3(b). The entire MK/MMK and its magnitudes of rainfall over monthly, annual and seasonal time steps are shown in Table 4.

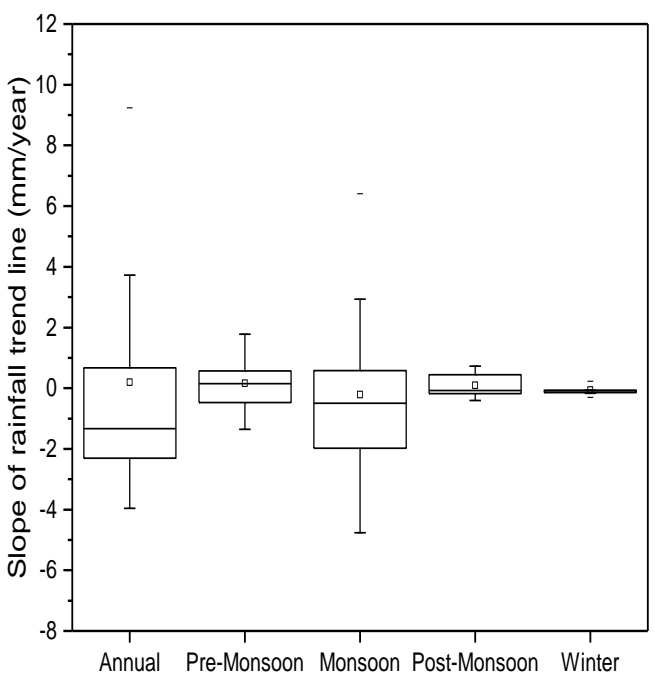

Figure 3(b): Box plot of the Theil-Sen's slopes in annual an d seasonal time step

Table 4: Results of Mann-Kendall test with Sen's slope estimator for different NE states of India during 1901-2015

\begin{tabular}{|c|c|c|c|c|c|c|c|c|c|c|c|c|c|c|c|c|c|}
\hline$\overline{\mathrm{MK}}$ & Jan & Feb & Mar & Apr & May & Jun & Jul & Aug & Sep & Oct & Nov & Dec & Annual & Pre-Monsoon & Monsoon & Post-Monsoon & Winter \\
\hline Arunachal Pradesh & -0.435 & 1.267 & 1.849 & 0.169 & -0.479 & $-2.086 \mathrm{a}$ & $-2.105 \mathrm{a}$ & $-3.075 \mathrm{a}$ & -1.46 & -0.655 & -0.525 & 0.179 & -1.281 & 1.027 & $-2.816 a$ & -0.861 & 0.972 \\
\hline Assam & -1.839 & -1.165 & -0.653 & -1.603 & -0.759 & $-2.180 \mathrm{a}$ & -0.744 & $-2.872 \mathrm{a}$ & -1.532 & -0.527 & -1.184 & 0.196 & $-3.423 \mathrm{a}$ & -1.736 & $-3.360 \mathrm{a}$ & -1.025 & $-2.391 \mathrm{a}$ \\
\hline Manipur & -0.743 & -1.682 & -0.706 & -0.817 & $2.318 \mathrm{~b}$ & -0.331 & 0.863 & -0.106 & 1.216 & 0.065 & -1.540 & 0.254 & 0.024 & 0.515 & -0.019 & -0.452 & -1.690 \\
\hline Meghalaya & 0.111 & -0.848 & 0.167 & 0.029 & $2.780 \mathrm{~b}$ & $4.066 \mathrm{~b}$ & $4.153 \mathrm{~b}$ & 1.387 & 1.750 & $2.412 \mathrm{~b}$ & -0.321 & $2.149 \mathrm{~b}$ & $4.165 \mathrm{~b}$ & $2.175 \mathrm{~b}$ & $3.657 \mathrm{~b}$ & $2.490 \mathrm{~b}$ & -1.317 \\
\hline Mizoram & -0.885 & -0.585 & -0.184 & -1.218 & $2.246 \mathrm{~b}$ & $2.507 \mathrm{~b}$ & $4.041 \mathrm{~b}$ & $2.582 \mathrm{~b}$ & $2.161 \mathrm{~b}$ & $2.586 \mathrm{~b}$ & -0.094 & 1.176 & $3.867 \mathrm{~b}$ & 0.742 & $4.544 \mathrm{~b}$ & $2.151 \mathrm{~b}$ & -1.124 \\
\hline Nagaland & $-2.707 \mathrm{a}$ & $-2.545 \mathrm{a}$ & $-1.994 \mathrm{a}$ & $-4.196 \mathrm{a}$ & -1.769 & $-3.147 \mathrm{a}$ & -0.981 & $-2.282 \mathrm{a}$ & -1.929 & -1.327 & $-2.071 \mathrm{a}$ & -0.888 & $-5.383 a$ & $-3.887 \mathrm{a}$ & $-3.846 \mathrm{a}$ & $-2.064 \mathrm{a}$ & $-3.72 \mathrm{a}$ \\
\hline Sikkim & 1.429 & 1.939 & $3.785 \mathrm{~b}$ & $4.249 \mathrm{~b}$ & 1.905 & $-2.480 a$ & $-2.891 \mathrm{a}$ & $-5.032 \mathrm{a}$ & -1.421 & 1.912 & 1.354 & $2.629 \mathrm{~b}$ & -1.871 & $4.467 \mathrm{~b}$ & -4.641 a & 1.830 & $2.407 \mathrm{~b}$ \\
\hline Tripura & -1.561 & -0.952 & -1.472 & $-2.093 \mathrm{a}$ & 1.245 & -1.697 & 1.199 & -0.273 & -0.764 & 0.249 & -0.878 & $2.714 \mathrm{~b}$ & -1.148 & -0.877 & -0.887 & -0.285 & -1.806 \\
\hline West Bengal & -0.135 & -1.346 & -0.261 & 0.940 & -0.425 & -0.203 & 1.714 & -0.338 & 1.702 & 0.788 & 0.534 & 1.454 & 1.037 & -0.073 & 1.453 & 0.783 & -1.172 \\
\hline Sen's Slope & Jan & Feb & Mar & Apr & May & Jun & Jul & Aug & Sep & Oct & Nov & Dec & Annual & Pre-Monsoon & Monsoon & Post-Monsoon & Winter \\
\hline Arunachal Pradesh & -0.026 & 0.141 & 0.331 & 0.050 & -0.173 & -0.838 & -0.830 & -1.321 & -0.477 & -0.129 & -0.022 & 0.004 & -2.304 & 0.565 & -3.225 & -0.194 & 0.137 \\
\hline Assam & -0.056 & -0.071 & -0.085 & -0.305 & -0.184 & -0.508 & -0.162 & -0.615 & -0.302 & -0.076 & -0.045 & 0.003 & -2.332 & -0.564 & -1.339 & -0.176 & -0.164 \\
\hline Manipur & -0.007 & -0.090 & -0.086 & -0.133 & 0.477 & -0.073 & 0.182 & -0.020 & 0.200 & 0.016 & -0.067 & 0.000 & 0.021 & 0.145 & -0.011 & -0.105 & -0.124 \\
\hline Meghalaya & 0.000 & -0.037 & 0.023 & 0.008 & 1.039 & 2.344 & 2.408 & 0.519 & 0.544 & 0.656 & -0.010 & 0.011 & 9.241 & 1.060 & 6.404 & 0.721 & -0.085 \\
\hline Mizoram & -0.002 & -0.025 & -0.022 & -0.300 & 0.630 & 0.728 & 0.961 & 0.494 & 0.499 & 0.467 & 0.000 & 0.000 & 3.732 & 0.314 & 2.932 & 0.443 & -0.070 \\
\hline Nagaland & -0.110 & -0.172 & -0.264 & -0.724 & -0.321 & -0.634 & -0.206 & -0.451 & -0.334 & -0.223 & -0.100 & -0.015 & -3.956 & -1.356 & -1.973 & -0.408 & -0.303 \\
\hline Sikkim & 0.053 & 0.118 & 0.531 & 0.821 & 0.411 & -0.984 & -1.414 & -1.805 & -0.506 & 0.357 & 0.041 & 0.031 & -2.027 & 1.782 & -4.764 & 0.445 & 0.232 \\
\hline Tripura & -0.007 & -0.050 & -0.223 & -0.716 & 0.471 & -0.621 & 0.350 & -0.056 & -0.165 & 0.051 & -0.019 & 0.000 & -1.333 & -0.478 & -0.494 & -0.081 & -0.142 \\
\hline West Bengal & -0.001 & -0.047 & -0.015 & 0.083 & -0.053 & -0.044 & 0.313 & -0.061 & 0.317 & 0.146 & 0.012 & 0.004 & 0.672 & -0.023 & 0.577 & 0.152 & -0.068 \\
\hline
\end{tabular}

Where, a Negative significant at the level of $5 \%$ and b Positive significant at the level of 5\% 


\subsection{Rainfall variabilityin monthly, annual and seasonal rainfall over North- Eastern states}

For agriculture, it is important to understand the seasonal variations of precipitation in order to obtain a precise assessment of supplemental water requirements (Gajbhiye et al. 2015).The analysis of the variability in rainfall patterns using CV for 1901-2015 for the different states of NorthEastern India indicates that theinter-annual and seasonal variability of rainfall shown in Figure 4(a-e). Variation is lowestfor annual and monsoon precipitation when minimum valuesof $\mathrm{CV}$ are $10.56 \%$ and $29.52 \%$, respectively. In contrast, minimum values of $\mathrm{CV}$ for rainfall in the other seasons are $36.36 \%$ (post-monsoon), $48.35 \%$ (winter) and 22 $\%$ (pre-monsoon). The seasonal precipitation variability is highest in Mizoram for three seasons: $91.92 \%$ for winter, $34.31 \%$ for monsoon and $73.54 \%$ for post-monsoon, and $34.36 \%$, for the pre-monsoon season. The spatial presentation of the CV values is shown in Figure 4(a-e). Regions with higher inter-annual variability in rainfall are more susceptible to floods and droughts (Pandey and Ramasastri 2002; Turkes,1996)

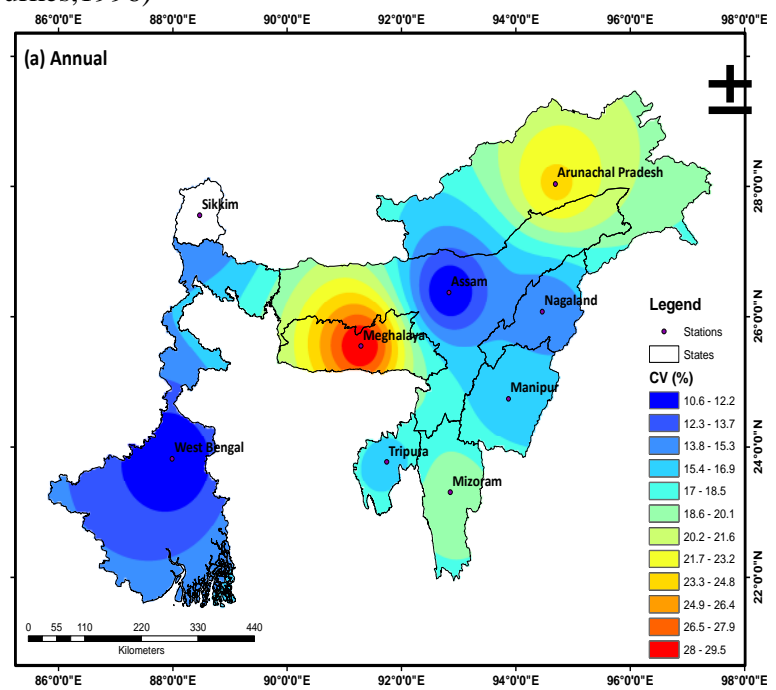

Figure 4(a): Rainfall variability $(\% \mathrm{CV})$ in annual time series during 1901-2015

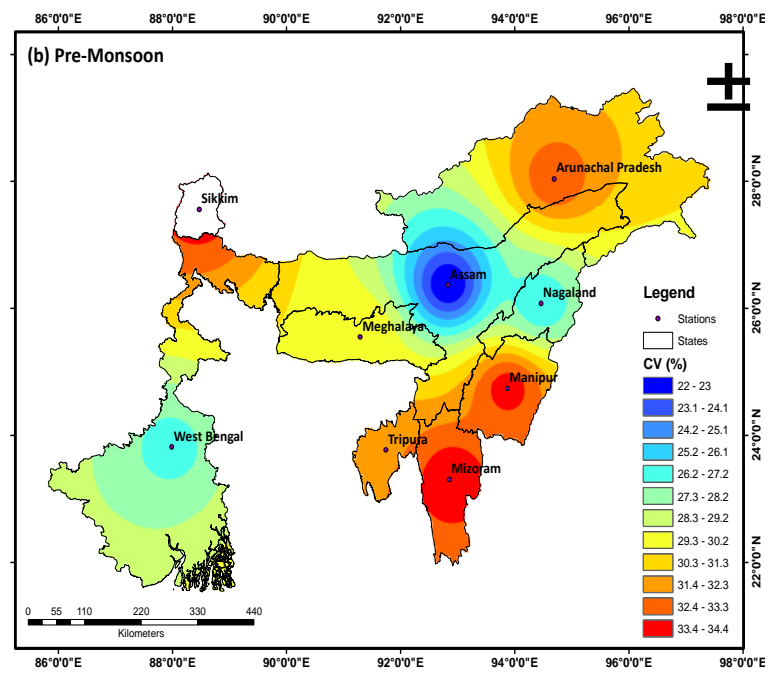

Figure 4(b): Rainfall variability $(\% \mathrm{CV})$ in pre-monsoon season during 1901-2015

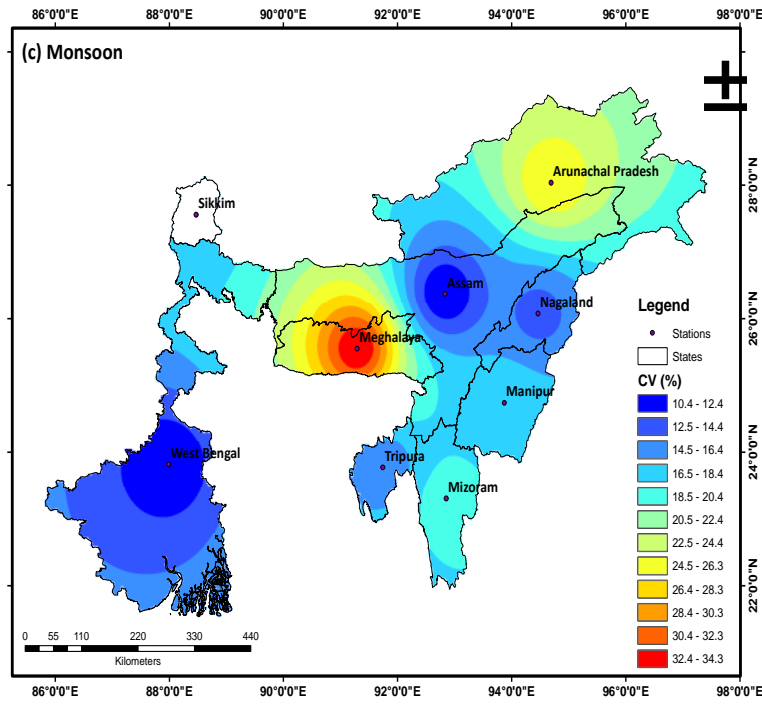

Figure 4(c): Rainfall variability $(\% \mathrm{CV})$ in monsoon season during 1901-2015

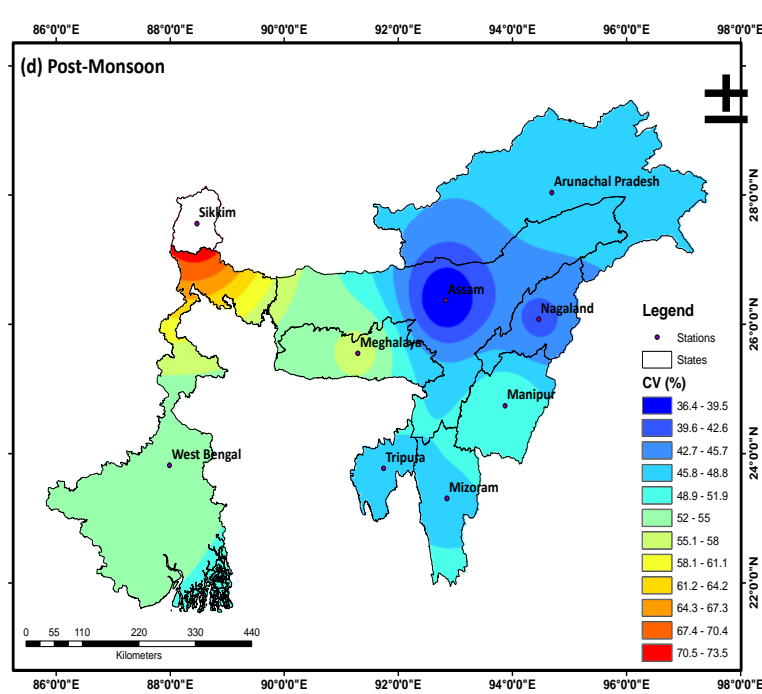

Figure 4(d): Rainfall variability (\%CV) in post-monsoon season during 1901-2015

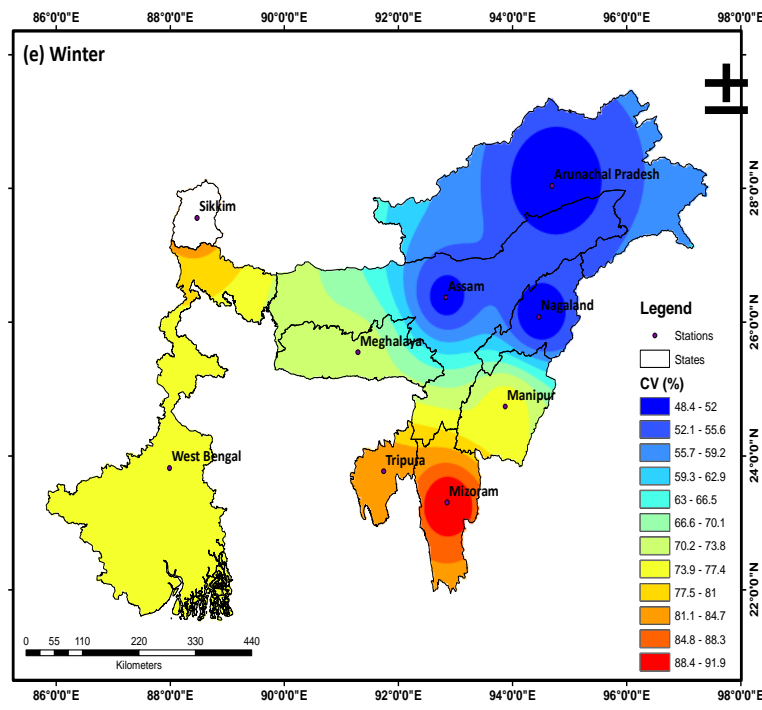

Figure 4(e): Rainfall variability (\%CV) in winter season during 


\section{CONCLUSION}

Trends and variability of monthly, annual and seasonal rainfall time series were analyzed for nine states of NorthEastern zone of India. The Mann-Kendall and Sen Slope estimation test were used to detect rainfall trends, and the Mann-Whitney-Pettitt and Standard Normal Homogeneity Test were used to identify possible change point's detection in rainfall time series during the 115-year period. From the results of the study, it is concluded that annual, monsoon and winter precipitation decreased in all the State during 19012015. The most probable year of change in the different state are different as shown in Table 3. During 1901-2015, the monthly time series are showed decreasing trends (significant or non-significant) except the December (positive trend) month. Overall, annual, monsoon and winter precipitation indicate declining trends whereas pre-monsoon rainfall shows most of the increasing trends at all stations during the whole period. In monthly time steps, the lowest value (Sikkim) for the slope of rainfall $(-1.805 \mathrm{~mm} / \mathrm{year})$ trend line was found in August month during 1901-2015, and the highest value (Meghalaya) for the slope of rainfall $(2.408 \mathrm{~mm} /$ year $)$ trend line was found in July month during 1901-2015. In annual and seasonal time steps, the lowest value (Sikkim) for the slope of rainfall $(-4.764 \mathrm{~mm} / \mathrm{year})$ trend line was found in the monsoon season during 1901-2015, and the highest value (Meghalaya) for the slope of rainfall $(9.241 \mathrm{~mm} /$ year $)$ trend line was found in the annual time scale during 1901- 2015. Thus decreasing rainfall in annual and seasonal basin indicates the possibility of drought condition or water scarcity. These will have an adverse effect on rain-fed agriculture as well as sustainable development of the state. For the study of weather phenomenon, the rainfall is an important factor which is responsible for climate change. However, climate change and its behavior is also complex phenomenon which depends upon natural and man-made factors. Evaluation of the long term trend of rainfall is very important for further climate studies. The results from the study can be useful for planning and managing the water resources, agriculture and sustainable development of the state and also important for any strategic planning for future adaptation and mitigation.

\section{REFERENCES}

[1] Aitken, A. P. (1973). Assessing systematic errors in rainfall-runoff models. Journal of Hydrology, 20(2), 121136.

[2] Alexander, L. V., Zhang, X., Peterson, T. C., Caesar, J., Gleason, B., Klein Tank, A. M. G., ... \& Tagipour, A. (2006). Global observed changes in daily climate extremes of temperature and precipitation. Journal of Geophysical Research: Atmospheres, 111(D5).

[3] Alexandersson, H. (1986). A homogeneity test applied to precipitation data. International Journal of Climatology, 6(6), 661-675.

[4] Alexandersson, H., \& Moberg, A. (1997). Homogenization of Swedish temperature data. Part I: Homogeneity test for linear trends. International Journal of climatology, 17(1), 25-34.

[5] Arnold JG, Allen PM. 1996. Estimating hydrologic budgets for three Illinois watersheds. Journal of Hydrology 176(1-4): 57-77.

[6] Aziz, O. I. A., \& Burn, D. H. (2006). Trends and variability in the hydrological regime of the Mackenzie River Basin. Journal of hydrology, 319(1), 282-294.
[7] Basistha, A., Arya, D. S., \& Goel, N. K. (2009). Analysis of historical changes in rainfall in the Indian Himalayas. International Journal of Climatology, 29(4), 555-572.

[8] Bayazit, M., \& Önöz, B. (2007). To prewhiten or not to prewhiten in trend analysis?. Hydrological Sciences Journal, 52(4), 611-624.

[9] Bayazit, M., \& Önöz, B. (2007). To prewhiten or not to prewhiten in trend analysis?. Hydrological Sciences Journal, 52(4), 611-624.

[10] Bradley, R. S., Diaz, H. F., Eischeid, J. K., Jones, P. D., Kelly, P. M., \& Goodess, C. M. (1987). Precipitation fluctuations over Northern Hemisphere land areas since the mid-19th century. Science, 237(4811), 171-175.

[11] Brunetti, M., Buffoni, L., Mangianti, F., Maugeri, M., \& Nanni, T. (2004). Temperature, precipitation and extreme events during the last century in Italy. Global and planetary change, $40(1), 141-149$.

[12] Brunetti, M., Buffoni, L., Mangianti, F., Maugeri, M., \& Nanni, T. (2004). Temperature, precipitation and extreme events during the last century in Italy. Global and planetary change, 40(1), 141-149.

[13] Buffoni, L., Maugeri, M., \& Nanni, T. (1999). Precipitation in Italy from 1833 to 1996 . Theoretical and Applied Climatology, 63(1), 33-40.

[14] Chandniha, S. K., Kansal, M. L., \& Anvesh, G. (2014). Watershed Sustainability Index Assessment of a Watershed in Chhattisgarh, India. Current World Environment, 9(2), 403.

[15] Chandniha, S. K., Meshram, S. G., Adamowski, J. F., \& Meshram, C. (2016). Trend analysis of precipitation in Jharkhand State, India. Theoretical and Applied Climatology, 1-14.

[16] Chaudhary, A., Abhyankar, V. P., 1979. Does precipitation pattern foretell Gujarat climate becoming arid Mausam, 30, pp. 85-90

[17] Chen, F., Xu, Q., Chen, J., Birks, H. J. B., Liu, J., Zhang, S., ... \& Wang, Z. (2015). East Asian summer monsoon precipitation variability since the last deglaciation. Scientific reports, 5 .

[18] Chowdhury, M. S. H., Gudmundsson, C., Izumiyama, S., Koike, M., Nazia, N., Rana, M. P., ... \& Redowan, M. (2014). Community attitudes toward forest conservation programs through collaborative protected area management in Bangladesh. Environment, development and sustainability, 16(6), 1235-1252.

[19] Cubasch, U., Meehl, G. A., Boer, G. J., Stouffer, R. J., Dix, M., Noda, A., ... \& Yap, K. S. (2001). Projections of future climate change., in: JT Houghton, Y. Ding, DJ Griggs, M. Noguer, PJ Van der Linden, X. Dai, K. Maskell, and CA Johnson (eds.): Climate Change 2001: The Scientific Basis: Contribution of Working Group I to the Third Assessment Report of the Intergovernmental Panel, 526-582.

[20] Dash, S. K., Jenamani, R. K., Kalsi, S. R., \& Panda, S. K. (2007). Some evidence of climate change in twentieth-century India. Climatic change, 85(3), 299 321. 
[21] Déry, S. J., \& Wood, E. F. (2005). Decreasing river discharge in northern Canada. Geophysical Research Letters, 32(10).

[22] Déry, S. J., \& Wood, E. F. (2005). Decreasing river discharge in northern Canada. Geophysical Research Letters, 32(10).

[23] Déry, S. J., \& Wood, E. F. (2005). Decreasing river discharge in northern Canada. Geophysical Research Letters, 32(10).

[24] Dinpashoh, Y., Jhajharia, D., Fakheri-Fard, A., Singh, V. P., \& Kahya, E. (2011). Trends in reference crop evapotranspiration over Iran. Journal of Hydrology, 399(3), 422-433.

[25] Dinpashoh, Y., Jhajharia, D., Fakheri-Fard, A., Singh, V. P., \& Kahya, E. (2011). Trends in reference crop evapotranspiration over Iran. Journal of Hydrology, 399(3), 422-433.

[26] Douglas, E. M., Vogel, R. M., \& Kroll, C. N. (2000). Trends in floods and low flows in the United States: impact of spatial correlation. Journal of hydrology, 240(1), 90-105.

[27] Duhan, D., \& Pandey, A. (2013). Statistical analysis of long term spatial and temporal trends of precipitation during 1901-2002 at Madhya Pradesh, India. Atmospheric Research, 122, 136-149.

[28] Easterling, D. R., Evans, J. L., Groisman, P. Y., Karl, T. R., Kunkel, K. E., \& Ambenje, P. (2000). Observed variability and trends in extreme climate events: a brief review. Bulletin of the American Meteorological Society, 81(3), 417-425.

[29] Fujibe, F., Yamazaki, N., Katsuyama, M., \& Kobayashi, K. (2005). The increasing trend of intense precipitation in Japan based on four-hourly data for a hundred years. Sola, 1, 41-44.

[30] García-Ruiz, J. M., López-Moreno, J. I., VicenteSerrano, S. M., Lasanta-Martínez, T., \& Beguería, S. (2011). Mediterranean water resources in a global change scenario. Earth-Science Reviews, 105(3), 121-139.

[31] Goswami, B. N., Venugopal, V., Sengupta, D., Madhusoodanan, M. S., \& Xavier, P. K. (2006). Increasing trend of extreme rain events over India in a warming environment. Science, 314(5804), 1442-1445.

[32] Groisman, P. Y., Knight, R. W., \& Karl, T. R. (2012). Changes in intense precipitation over the central United States. Journal of Hydrometeorology, 13(1), 47-66.

[33] Groisman, P. Y., Knight, R. W., Easterling, D. R., Karl, T. R., Hegerl, G. C., \& Razuvaev, V. N. (2005). Trends in intense precipitation in the climate record. Journal of climate, 18(9), 1326-1350.

[34] Guhathakurta, P., \& Rajeevan, M. (2008). Trends in the rainfall pattern over India. International Journal of Climatology, 28(11), 1453-1469.

[35] Guttman, N. B. (1999). Accepting the standardized precipitation index: a calculation algorithm. JAWRA Journal of the American Water Resources Association, 35(2), 311-322.

[36] Hamed, K. H., \& Rao, A. R. (1998). A modified MannKendall trend test for autocorrelated data. Journal of
Hydrology, 204(1-4), 182-196.

[37] Hasan, M. M., \& Dunn, P. K. (2011). Two Tweedie distributions that are near- optimal for modelling monthly rainfall in Australia. International Journal of Climatology, 31(9), 1389-1397.

[38] Hayes, S. C., Strosahl, K. D., \& Wilson, K. G (1999). Acceptance and commitment therapy: An experiential approach to behavior change. Guilford Press.

[39] IPCC, 2007: Solomon, S., Qin, D., Manning, M., Chen, Z., Marquis, M., Averyt, K. B., ... \& Miller, H. L. (2007) summary for policymakers. Climate change, 2007, 79.

[40] IPCC, 2014: Edenhofer, O., Pichs-Madruga, R., Sokona, Y., Farahani, E., Kadner, S., Seyboth, K., ... \& Kriemann, B. (2014). IPCC, 2014: summary for policymakers. Climate change.

[41] Iwashima, T., \& Yamamoto, R. (1993). NOTES AND CORRESPONDENCE: A Statistical Analysis of the Extreme Events: Long-Term Trend of Heavy Daily Precipitation. Journal of the Meteorological Society of Japan. Ser. II, 71(5), 637-640.

[42] Jaagus, J. (2006). Climatic changes in Estonia during the second half of the 20th century in relationship with changes in large-scale atmospheric circulation. Theoretical and Applied Climatology, 83(1), $77-88$

[43] Jain, S. K., \& Kumar, V. (2012). Trend analysis of rainfall and temperature data for India. Current Science, $37-49$.

[44] Jhajharia, D., Dinpashoh, Y., Kahya, E., Singh, V. P., \& Fakheri- Fard, A. (2012). Trends in reference evapotranspiration in the humid region of northeast India. Hydrological Processes, 26(3), 421-435.

[45] Kendall, M. (1975). Multivariate analysis. Charles Griffin.

[46] Khaliq, M. N., Ouarda, T. B. M. J., St- Hilaire, A., \& Gachon, P. (2007). Bayesian change- point analysis of heat spell occurrences in Montreal, Canada. International journal of climatology, 27(6), 805-818

[47] Khan, S., Gabriel, H. F., \& Rana, T. (2008). Standard precipitation index to track drought and assess impact of rainfall on watertables in irrigation areas. Irrigation and Drainage Systems, 22(2), 159-177.

[48] Krishnakumar, K. N., Rao, G. P., \& Gopakumar, C. S (2009). Rainfall trends in twentieth century over Kerala, India. Atmospheric environment, 43(11), 1940-1944.

[49] Kumar, K. K., \& Parikh, J. (2001). Indian agriculture and climate sensitivity. Global environmental change, 11(2), 147-154.

[50] Kumar, V., Jain, S. K., \& Singh, Y. (2010). Analysis of long-term rainfall trends in India. Hydrological Sciences Journal-Journal des Sciences Hydrologiques, 55(4), 484496.

[51] Kumar, V., Jain, S. K., \& Singh, Y. (2010). Analysis of long-term rainfall trends in India. Hydrological Sciences Journal-Journal des Sciences Hydrologiques, 55(4), 484 496.

[52] Kumar, V., Jain, S. K., and Singh, Y. (2010). "Analysis of long-term rainfall trends in India." Hydrological 
Sciences Journal, 55(4), 484-496.

[53] Lacombe, G., \& McCartney, M. (2014). Uncovering consistencies in Indian rainfall trends observed over the last half century. Climatic change, 123(2), 287-299.

[54] Lacombe, G., \& McCartney, M. (2014). Uncovering consistencies in Indian rainfall trends observed over the last half century. Climatic change, 123(2), 287-299.

[55] Lal, M., Nozawa, T., Emori, S., Harasawa, H., Takahashi, K., Kimoto, M., ... \& Numaguti, A. (2001). Future climate change: Implications for Indian summer monsoon and its variability. Current science, 1196-1207.

[56] Lettenmaier, D. P., Wood, E. F., \& Wallis, J. R. (1994). Hydro-climatological trends in the continental United States, 1948-88. Journal of Climate, 7(4), 586-607.

[57] Lloyd- Hughes, B., \& Saunders, M. A. (2002). A drought climatology for Europe. International journal of climatology, 22(13), 1571-1592.

[58] Loo, Y. Y., Billa, L., \& Singh, A. (2015). Effect of climate change on seasonal monsoon in Asia and its impact on the variability of monsoon rainfall in Southeast Asia. Geoscience Frontiers, 6(6), 817-823.

[59] Loukas, A., \& Vasiliades, L. (2004). Probabilistic analysis of drought spatiotemporal characteristics inThessaly region, Greece. Natural Hazards and Earth System Science, 4(5/6), 719-731.

[60] Luis, M. D., Raventós, J., González-Hidalgo, J. C., Sánchez, J. R., \& Cortina, J. (2000). Spatial analysis of rainfall trends in the region of Valencia (East Spain). Int. J. Climatol, 20(12), 1451-1469.

[61] Maheras, P. (1988). Changes in precipitation conditions in the western Mediterranean over the last century. International Journal of Climatology, 8(2), 179-189

[62] Mann, H. B. (1945). Nonparametric tests against trend. Econometrica: Journal of the Econometric Society, 245-259.

[63] Mann, H. B. (1945). Nonparametric tests against trend. Econometrica: Journal of the Econometric Society, 245-259.

[64] Manton, M. J., Della- Marta, P. M., Haylock, M. R., Hennessy, K. J., Nicholls, N., Chambers, L. E., ... \& Inape, K. (2001). Trends in extreme daily rainfall and temperature in Southeast Asia and the South Pacific: 1961-1998. International Journal of Climatology, 21(3), 269-284.

[65] McMichael, A. J., \& Haines, A. (1997). Global climate change: the potential effects on health. BMJ: British Medical Journal, 315(7111), 805.

[66] Mirza, M. M. Q. (2002). Global warming and changes in the probability of occurrence of floods in Bangladesh and implications. Global environmental change, 12(2), 127138

[67] Mirza, M. Q., Warrick, R. A., Ericksen, N. J., \& Kenny, G. J. (1998). Trends and persistence in precipitation in the Ganges, Brahmaputra and Meghna river basins. Hydrological Sciences Journal, 43(6), 845-858.

[68] Mirza, M. Q., Warrick, R. A., Ericksen, N. J., \& Kenny, G. J. (1998). Trends and persistence in precipitation in the Ganges, Brahmaputra and Meghna river basins. Hydrological Sciences Journal, 43(6), 845-858.

[69] Mishra, A. K., \& Desai, V. R. (2005). Drought forecasting using stochastic models. Stochastic Environmental Research and Risk Assessment, 19(5), 326-339.

[70] Mishra, A. K., Özger, M., \& Singh, V. P. (2009). An entropy-based investigation into the variability of precipitation. Journal of Hydrology, 370(1), 139-154.

[71] Mondal, A., Kundu, S., \& Mukhopadhyay, A. (2012). Rainfall trend analysis by Mann-Kendall test: A case study of north-eastern part of Cuttack district, Orissa. International Journal of Geology, Earth and Environmental Sciences, 2(1), 70-78.

[72] Mooley, D. A., \& Parthasarathy, B. (1984). Fluctuations in all-India summer monsoon rainfall during 18711978. Climatic Change, 6(3), 287-301.

[73] Mooley, D. A., \& Parthasarathy, B. (1984). Fluctuations in all-India summer monsoon rainfall during 18711978. Climatic Change, 6(3), 287-301.

[74] Mooley, D. A., \& Parthasarathy, B. (1984). Fluctuations in all-India summer monsoon rainfall during 18711978. Climatic Change, 6(3), 287-301.

[75] Murphy, B. F., \& Timbal, B. (2008). A review of recent climate variability and climate change in southeastern Australia. International journal of Climatology, 28(7), 859-879.

[76] Nicholls, N., \& Lavery, B. (1992). Australian rainfall trends during the twentieth century. International Journal of Climatology, 12(2), 153-163.

[77] Novotny, E. V., \& Stefan, H. G. (2007). Stream flow in Minnesota: indicator of climate change. Journal of Hydrology, 334(3), 319-333.

[78] Oguntunde, P. G., Abiodun, B. J., \& Lischeid, G. (2011). Rainfall trends in Nigeria, 1901-2000. Journal of Hydrology, 411(3), 207-218.

[79] Osborn, T. J., \& Briffa, K. R. (2000). Revisiting timescale-dependent reconstruction of climate from treering chronologies. Dendrochronologia, 18, 9-25.

[80] Partal, T., \& Kahya, E. (2006). Trend analysis in Turkish precipitation data. Hydrological processes, 20(9), 2011 2026.

[81] Partal, T., \& Kahya, E. (2006). Trend analysis in Turkish precipitation data. Hydrological processes, 20(9), 20112026.

[82] Patra, J. P., Mishra, A., Singh, R., \& Raghuwanshi, N. S. (2012). Detecting rainfall trends in twentieth century (1871-2006) over Orissa State, India. Climatic Change, 111(3-4), 801-817.

[83] Pettitt, A. N. (1979). A non-parametric approach to the change-point problem. Applied statistics, 126-135.

[84] Pettitt, A. N. (1979). A non-parametric approach to the change-point problem. Applied statistics, 126-135.

[85] Pettitt, A. N. (1980). A simple cumulative sum type statistic for the change-point problem with zero-one observations. Biometrika, 67(1), 79-84. 
[86] Praskievicz, S., \& Chang, H. (2009). A review of hydrological modeling of basin-scale climate change and urban development impacts. Progress in Physical Geography, 33(5), 650-671.

[87] Rajeevan, M., Pai, D. S., Kumar, R. A., \& Lal, B. (2007). New statistical models for long-range forecasting of southwest monsoon rainfall over India. Climate Dynamics, 28(7-8), 813-828.

[88] Rauch, W., \& DeToffol, S. (2006, December). Climate change induced trends in high resolution rainfall. In Proceedings of the 7th International Workshop on Precipitation in Urban Areas: Extreme Precipitation, Multi source Data Measurement and Uncertainty (pp. 7 $10)$.

[89] Rind, D., Goldberg, R., \& Ruedy, R. (1989). Change in climate variability in the 21 st century. Climatic change, 14(1), 5-37.

[90] Roy, S. S., \& Rouault, M. (2013). Spatial patterns of seasonal scale trends in extreme hourly precipitation in South Africa. Applied Geography, 39, 151-157.

[91] Sarker, R. P., \& Thapliyal, V. (1988). Climate change and variability. Mausam, 39, 127-138.

[92] Sen Roy, S., \& Balling, R. C. (2004). Trends in extreme daily precipitation indices in India. International Journal of climatology, 24(4), 457-466.

[93] Shi, G., Cai, W., Cowan, T., Ribbe, J., Rotstayn, L., \& Dix, M. (2008). Variability and trend of North West Australia rainfall: observations and coupled climate modeling. Journal of Climate, 21(12), 2938-2959.

[94] Shiau, J. T. (2006). Fitting drought duration and severity with two-dimensional copulas. Water resources management, 20(5), 795-815.

[95] Shrestha, A. B., Wake, C. P., Dibb, J. E., \& Mayewski, P. A. (2000). Precipitation fluctuations in the Nepal Himalaya and its vicinity and relationship with some large scale climatological parameters. International Journal of Climatology, 20(3), 317-327.

[96] Sikka, D. R., \& Gadgil, S. (1980). On the maximum cloud zone and the ITCZ over Indian, longitudes during the southwest monsoon. Monthly Weather Review, 108(11), 1840-1853.

[97] Singh, N., \& Sontakke, N. A. (2002). On climatic fluctuations and environmental changes of the IndoGangetic plains, India. Climatic Change, 52(3), 287-313.

[98] Singh, P., Kumar, V., Thomas, T., \& Arora, M. (2008). Changes in rainfall and relative humidity in river basins in northwest and central India. Hydrological Processes, 22(16), 2982-2992.

[99] Singh, P., Kumar, V., Thomas, T., \& Arora, M. (2008). Changes in rainfall and relative humidity in river basins in northwest and central India. Hydrological Processes, 22(16), 2982-2992.

[100] Singh, V. P., \& Woolhiser, D. A. (2002). Mathematical modeling of watershed hydrology. Journal of hydrologic engineering, 7(4), 270-292.

[101] Sinha Ray, K. C., \& De, U. S. (2003). Climate change in India as evidenced from instrumental records. Bulletin of the World Meteorological
Organization, 52(1), 53-58.

[102] Sinha Ray, K. C., \& Srivastava, A. K. (1999). Is there any change in extreme events like droughts and heavy rainfall. INTROPMET-97, IIT New Delhi, 2-5.

[103] Some'e, B. S., Ezani, A., \& Tabari, H. (2012). Spatiotemporal trends and change point of precipitation in Iran. Atmospheric research, 113, 1-12.

[104] Some'e, B. S., Ezani, A., \& Tabari, H. (2012) Spatiotemporal trends and change point of precipitation in Iran. Atmospheric research, 113, 1-12.

[105] Srivastava, H. N., Sinha Ray, K. C., Dikshit, S. K., \& Mukhopadhaya, R. K. (1998). Trends in rainfall and radiation over India. Vayu Mandal, 1, 41-45.

[106] Stacy, E. W., \& Mihram, G. A. (1965). Parameter estimation for a generalized gamma distribution. Technometrics, 7(3), 349-358.

[107] Suppiah, R., \& Hennessy, K. J. (1998). Trends in total rainfall, heavy rain events and number of dry days in Australia, 1910-1990. International Journal of Climatology, 18(10), 1141-1164.

[108] Tabari, H., \& Aghajanloo, M. B. (2013). Temporal pattern of aridity index in Iran with considering precipitation and evapotranspiration trends. International Journal of Climatology, 33(2), 396-409.

[109] Tabari, H., \& Aghajanloo, M. B. (2013). Temporal pattern of aridity index in Iran with considering precipitation and evapotranspiration trends. International Journal of Climatology, 33(2), 396-409.

[110] Tabari, H., Abghari, H., \& Hosseinzadeh Talaee, P (2012). Temporal trends and spatial characteristics of drought and rainfall in arid and semiarid regions of Iran. Hydrological Processes, 26(22), 3351-3361.

[111] Tabari, H., Somee, B. S., \& Zadeh, M. R. (2011). Testing for long-term trends in climatic variables in Iran. Atmospheric Research, 100(1), 132-140.

[112] Tabari, H., Somee, B. S., \& Zadeh, M. R. (2011). Testing for long-term trends in climatic variables in Iran. Atmospheric Research, 100(1), 132-140.

[113] Tabari, H., Taye, M. T., \& Willems, P. (2015). Statistical assessment of precipitation trends in the upper Blue Nile River basin. Stochastic environmental research and risk assessment, 29(7), 1751-1761.

[114] Thapliyal, V., \& Kulshrestha, S. M. (1991). Climate changes and trends over India. Mausam, 42(4), 333-338.

[115] TUeRKEŞ, M., SUeMER, U. M., \& Kilic, G. (1996). ERRATUM: OBSERVED CHANGES IN MAXIMUM AND MINIMUM TEMPERATURES IN TURKEY. International Journal of Climatology, 16(10), 1195-1195

[116] Umran Komuscu, A. (1999). Using the SPI to analyze spatial and temporal patterns of drought in Turkey. Drought Network News (1994-2001), 49.

[117] Villarini, G., \& Vecchi, G. A. (2013). Projected increases in North Atlantic tropical cyclone intensity from CMIP5 models. Journal of Climate, 26(10), 32313240 . 
[118] Villarini, G., Smith, J. A., \& Vecchi, G. A. (2013). Changing frequency of heavy rainfall over the central United States. Journal of Climate, 26(1), 35

[119] Von Storch, H. (1999). Misuses of statistical analysis in climate research. In Analysis of Climate Variability (pp. 11-26). Springer Berlin Heidelberg.

[120] Wang, Y., \& Zhou, L. (2005). Observed trends in extreme precipitation events in China during 1961-2001 and the associated changes in large- scale circulation. Geophysical Research Letters, 32(9).

[121] Wang, Y., \& Zhou, L. (2005). Observed trends in extreme precipitation events in China during 1961-2001 and the associated changes in large- scale circulation. Geophysical Research Letters, 32(9).

[122] Westra, S., Alexander, L. V., \& Zwiers, F. W. (2013). Global increasing trends in annual maximum daily precipitation. Journal of Climate, 26(11), 39043918.

[123] Yue, S., Pilon, P., \& Cavadias, G. (2002). Power of the Mann-Kendall and Spearman's rho tests for detecting monotonic trends in hydrological series. Journal of hydrology, 259(1), 254-271.

[124] Yue, S., Pilon, P., \& Cavadias, G. (2002). Power of the Mann-Kendall and Spearman's rho tests for detecting monotonic trends in hydrological series. Journal of hydrology, 259(1), 254-271.

[125] Yue, S., Pilon, P., \& Cavadias, G. (2002). Power of the Mann-Kendall and Spearman's rho tests for detecting monotonic trends in hydrological series. Journal of hydrology, 259(1), 254-271.

[126] Zeng, N., Zhao, F., Collatz, G. J., Kalnay, E., Salawitch, R. J., West, T. O., \& Guanter, L. (2014). Agricultural Green Revolution as a driver of increasing atmospheric CO2 seasonal amplitude. Nature, 515(7527), 394.

[127] Zong-xue, X. U., \& Nan, Z. (2006). Long-term trend of precipitation in the Yellow River basin during the past 50 years. 地理研究, 25(1), 27-34. 